\title{
Oil Palm Plantation Development: An Emerging Threat to Biodiversity Conservation in Oban Division of Cross River National Park, Nigeria
}

\author{
Ikyaagba, E .T. ${ }^{1 \& 2}$, Jimoh, S.O ${ }^{2}$, Dagba, B. I ${ }^{1}$, Tee, T. N. ${ }^{1}$, Ancha, P. U ${ }^{1}$ Tume, ${ }^{1}$ \\ ${ }^{I}$ Departme Int of Social and Environmental Forestry, University of Agriculture, Makurdi, Nigeria \\ ${ }^{2}$ Department of Forest Resources Management, University of Ibadan, Ibadan, Nigeria
}

*Corresponding Author: Ikyaagba, E .T., DepartmeInt of Social and Environmental Forestry, University of Agriculture, Makurdi, Nigeria

Received Date: 10-11-2016

Accepted Date: 15-11-2016

Published Date: 17-05-2017

\begin{abstract}
Nigeria poverty level is rated very high as over $70 \%$ of the population is living on one dollar in a day. Cross River State is considered as an economically back ward State in Nigeria. However, the State is located in the only biodiversity hotspot in West Africa where ecological conditions favour oil palm production. With the intrusion of Malaysian big oil palm companies in the state with a promise to improve the living standard of the people; the quick and fast spread of oil palm plantation in the state, especially in Oban hills region, form a great threat to biodiversity conservation in the area. This paper takes a look at the economic and environmental impacts of oil palm plantation expansion in the area. Oil palm production will improve the lives of rural poor as suggested by the oil palm preachers, but it will also disenfranchise other communities by deprive them of biodiversity benefits such as food, timber, fuel wood, and many others. It will drive to extinction some species of conservation concern and also put more pressure on Cross River national park. In view of this the paper recommends more researches across every taxa in order to generate empirical data that will guide sound and most informed decision making on biodiversity conservation in the area.
\end{abstract}

Keywords: Poverty, Oil Palm, Biodiversity hotspot, Conservation, Oban.

\section{INTRODUCTION}

In Nigeria over $70 \%$ of her population lives on less than a dollar a day (Ingwe et al, 2010). In Cross River where Oban region is found, Ingwe et al. (2010) submit that the poverty rate may be above the national figure. With this prevalence of poverty in the country, government and other stakeholders are always on the watch out for possible lead way.

Oil palm is being promoted as one of the economic crops in Nigeria; currently its establishment in large plantations is receiving greater attention as a strategy for poverty reduction in Nigeria (Ayodele, 2010). As pressure continue to mount on big oil palm industries in Asia to stop deforestation for oil palm plantation, the desperation by African countries including Nigeria to tackle poverty, has provided these Asia oil palm companies an opportunity to turn African high forests into fertile ground for oil palm expansion (Walter et al., 2011).
Key players in the oil palm sector always use key words like, economic development, poverty alleviation and nature conservation as ploy to achieve their goal (Walter et al., 2011). In Asia Wilcove and Koh (2010) believed that the failure to curb or slow down the conversion of tropical forests to oil palm in the region lies in the social, economic, and ecological realities surrounding oil palm production. In Nigeria Ayodele (2010) pointed out that oil palm development is an effective means of poverty alleviation because of the high yield and low cost of production, and so it should be given a special consideration. This many States including Cross Rive State are now promoting oil palm plantation development in their localities. This has stimulated the intrusion of big Malaysian oil palm companies such as PZ Wilmar in Cross River State, particularly in the Oban hill region; the only biodiversity hotspot in West Africa, which is among the top 25 biodiversity hot spots in the world (Myer et al., 2000).It is the only area with near intact largest block of contiguous forest in the region (Oates et 
al., 2004). The feeling is that, the future of the area is not secured (Bergl et al., 2006), as the area is labeled as one of the 19 tropical humid forest deforestation hotspots in West Africa (Oates et al., 2004). At present, there are at least 4 large oil palm plantations, such as Ayip Eku, Real oil, Calaro, Biase and new ones are coming up including five large rubber plantations.

Oban Division of CRNP is divided into two corridors, the West and East corridors. The Western corridor is made up of three Cells namely: Old Ekuri, Ifumkpa and Old Netim. These cells comprise of 8 villages. The Eastern Corridor comprises of Ekang Njage, Osomba, Oban, Aningeje and Nsofang and it is made up of 31 villages. This gives a total of 39 villages in the division

This paper therefore highlights the possible impacts associated with oil palm plantation development in the area.

\section{Renewed Interest in Oil Palm Production in Nigeria}

Before the discovery of crude oil in Nigeria, Nigeria was accounting for $43 \%$ of world oil palm production (Akangbe et al., 2011), this made her the leading producer as of the time. However, this position has long been lost to Malaysia and Indonesia. Today the country account for only $1.7 \%$ of the world production which cannot even meet the local demand of 2.7\% (Olagunju, 2008; Akangbe et al., 2011).

This drop in the production of oil palm is now a major concern in economic circle in Nigeria. This drop is linked to failure of Nigeria to embrace intensive oil palm plantation, unlike other Asia countries (Olagunju, 2008). Therefore, in her quest to retain her position in the world palm oil production and also quest to diversify the country's policy makers have now turns their attention to palm oil plantation development. In the last couple of years, the palm oil sectors in Nigeria has witnessed a remarkable level of prominence, and large corporations, from within and outside the country, are rushing to set up palm oil processing factories (Osagie, 2013). These companies have discovered a massive gap between local production and consumption of palm oil in the country, and also the zeal by Nigerian government to recover her lost position. Taking advantage of poor environmental policies on ground, every investor with funds is moving to set up palm oil refineries.
As a sign of Nigerian government consent to oil palm development in the country, on November 2012, President Goodluck Jonathan inaugurated the Calaro, Ibiae and Biase Oil Palm plantations in Cross River State, a multi-million naira agribusiness joint venture between PZ-Cussons and Wilmar International Limited (Osagie, 2013).

\section{Oil Palm And Nigerian Economy}

Oil palm is considered as one of the most important oil crop and also important food security crops in Nigeria based on its diverse usage (Akangbe et al., 2011). It is called crop of many values which underscored its economic importance as no part of the plant is considered a waste (Daramola et al., 2002). It contributes to livelihood of many rural Nigerian.

Highlighting the contributions of oil palm industry to economic development of Nigeria, Ahmed (2001) as cited by Olagunju (2008) pointed out that, if properly harness, the sectors will directly employ over 4 million and also create several millions indirectly jobs in other sectors. Osagie (2013) in his column point out that an average oil palm processing plant may employ about 200 people directly and indirectly, a moderate oil palm plantation that feeds such a plant with crude palm oil will employ over 5,000 people, and this is what the nation needs if the targets of poverty and unemployment reduction often preached by the Federal Government are ever to be met. It is true that oil-palm plantation will improve the lives of those workers (Rist et al., 2010). The question however is how many hectares of forested land that will be converted and how many families will be deprived of their lands? As submitted by Wilcove and Koh (2010) conversion of forests to oil-palm plantations can deprive local communities of the ability to utilize forest resources. They concluded that, there are serious human-rights issues associated with the expansion of oil-palm agriculture that needs further scrutiny.

A work by Walter et al. (2011) in Cameroun revealed that to establish a 60,000 ha of oil palm plantation can displace 38 villages with only seven of these villages having 194 households. If each household is comprises of two members this will give a total 388 people that will be displaced in only seven villages. The issue remains how many members of each household will be employed in the oil palm industries. These plantations when created, essential resources (water, firewood, food and 
other forest products and ecosystem services) that are free to the rural people will likely disappear leading to migration and increased pressure on protected areas (Walter et al., 2011).

In Cross River State forests are major assets for both government and rural communities because both derive substantive revenue from timber and non timber forest products (Sunderland, 2001; Ogar et al., 2005). In Akamkpa Local Government Area, where Oban diversion of CRNPis located, Offiong and Ita (2013) concluded that NTFPs contributes substantially to the rural household food security and development of the area. The major sources of these NTFPs such as Irvingia spp, bush meat, Gnetum and many others are primary and secondary forests (Nkwato et al., 2010; Offiong and Ita, 2013). If 39 communities in Oban Hill region that surrounds the National Park continue to loss their land to oil palm plantation. The conflict between communities and park officials will be on the increase as shown by Obong et al. (2013). They reported that farm encroachment, poaching and NTFPs collection were the major reasons for conflicts between park management and the communities. Increasing pressure on the park will defeat the aim for its establishment.

Those campaigning against oil palm expansion are regarded in some quarters as enemies of poor nations like Nigeria (Ayodele, 2010). The feeling is that oil palm production could generate money that could raise living standard and reduce poverty in those countries. The question is, is it money that is the problem of Nigeria economy or poor management of resources? How can we explain what happened with money generated when oil palm was the major cash crop and now money from crude oil? Is it now that oil palm will serve Nigeria from the scourge of poverty, when forest is considered as the lung of the world? (Khalid, 1995).

\section{The Threat of Oban Biodiversity}

Most of the biodiversity hotspots are located in the tropics where conditions are very good for oil palm production (Persey and Anhar, 2010, Wilcove and Koh, 2010). Butler and Laurence (2009) concluded that, due to large expanses of forested areas in the tropics, oil palm is likely to continue to replace tropical forest (Wilcove and Koh, 2010). This expansion scholars believed is the greatest threat to biodiversity (Fitzherbert, et al., 2008; Persey and anhar, 2010; Wilcove and Koh, 2010).
Other scholars argued that these threats depend largely on the extent to which oil palm expansion causes deforestation and on the extent to which oil palm maybe able to support biodiversity (Wilcove and Koh, 2010). In respect of the extend some scholars believed that, biodiversity is severely depleted by oil palm plantations (Fitzherbert, et al., 2008; Edward et al., 2010; Persey and Anhar, 2010; Wilcove and Koh, 2010). However in Nigeria Ayodele (2010) argued that oil palm production is not a threat to biodiversity. In his worlds these threats are "alleged threats", even when Butchart et al. (2004) point out that decline in biodiversity due to deforestation know no region. Confirming this submission, Wilcove and Koh (2010) stressed that a single hectare of forested land converted to oil palm represent a greater loss of biodiversity than logging of that same hectare.

It is established that oil palm generally held lower species richness and composition (Fitzherbert et al., 2008; Danielsen et al., 2009; Edward et al., 2010; Persey and Anhar, 2010 Wilcove and Koh, 2010). Oil palms are derived of forest specialist, in most cases are of greater conservation concern (Persey and Anhar, 2010).

In Oban hills region no single blue duiker was sighted in any of the three oil palm plantation surveyed, however, a total of 30 blue duiker were sighted in primary and 18 in the secondary forest (Jimoh et al., 2012). This agrees with the submission by Persey and Anhar (2010) that mammals react more adversely to oil palm plantation. Study by Jimoh et al., (2012) being the only known study of such in the area, one wanders what will be the status of other species which are not yet studied? All animals both small and large mammals as well as birds are affected (Danielsen et al., 1995; Aratrakan et al., 2006).

It has been shown that all taxa are impacted negatively by Oil palm plantation (Liow et al., 2001, Davis and Philips, 2005; Chey, 2006; Fitzherbert et al., 2008; Koh, 2008; Turner et al., 2008; Bruhl et al., 2009 Danielsen et al., 2009; Fayce et al., 2010; Foster et al., 2011). Due to the absence of major components of forest vegetation, forest specialist are normally replaced by few non-forest species that are favored by open and disturbed habitat ( Persey and Anchar, 2010). Based on their extensive review, Wilcove and Koh, (2010) concluded that oil palm Agriculture is the greatest immediate 
threat to biodiversity. Their conclusion was based on the extent to which forest are converted to oil palm.

Drawing from this conclusion we can say that, Oban hill region as biodiversity hotspot is also under intense pressure. This is coming from the fact that investors are now putting in about 300 million US dollar into oil palm development in Cross River by PZ Wilmar International Limited and most of this plantation are located around Oban hills region. With Cross River State government targeting over 20,000 jobs from oil palm plantation. PZ Wilmar is also targeting about 100,000 hectares of oil palm cultivation in Nigeria. Already it has taken possession of over 30,000 hectares of plantation, in Cross River around Oban hills region which they are massively replanting. PZ Wilmar has already taken over three oil palm plantation in the state; Calaro, Baise, Ibiae oil palm plantations.

As reported by Ugwu (2009) over 1, 356, 000 oil palm seedlings are produced in Cross River State annually. This translates into over 9,040ha of forested area that is being converted into oil palm plantation annually. If only a single hectares of forested land converted can cause a greater loss than logging, one wander what happen if over 9000 ha are being converted annually in Oban hills.

The area is not only experiencing oil palm expansion, Rubber plantations and other big companies are bringing in other crops on a very large scale. In 2011-2012, Danza farms acquire over 5000ha around Oban for Pineapple plantation.

One can argue that, the area is secured due to the presence of Cross River National Park. However the question is, does biodiversity occur only in the Protected Area (PA). What happened to those that occurred outside the PA? The fear expressed by Reid (1989) and Oates et al. (2004) about the future of the area is gradually setting in. Another fear is that, communities will continue to loss their land, and where not all members of the family will be engaged in the oil palm industries; most of them will turn to the PA as good land for farming. This fear was also expressed by Ite and Adams (1998). In his words the PA has failed to accomplish her mandates of protecting biodiversity in the area due to farm encroachment. With continued conversion of the land, one wonders whether the area will retain its status as highly diverse and endemic in West Africa in the next 10 years.

\section{RESEARCH NEED}

They key players in oil palm industries claimed that, campaign by green movement to reduce oil palm expansion is a way of thwarting economic growth of third world nations (Ayodele 2010). He further claimed that most or the environmental impacts said to be associated with oil palm are over flatted or misleading. Even though, these conclusions were not empirical, limited research works in Nigeria on the impact of oil palm could be the reason behind the poor judgment by many.

As reported by Turner et al. (2008) understanding the impact of oil palm expansion on all taxa is very vital as the area are being converted to oil palm plantation are increasing. Empirical data on these impacts will allow for informed judgment, about the real status of biodiversity in oil palm plantation but not to base our conclusion on questionnaire.

However, unlike other leading producers of oil palm Malaysia and Indonesia where a lot has been done in this regard (see review by Turner et al., 2008; Fitzherbert et al., Edward et al., 2010; Persey and Anhar, 2010) Nigeria being the third largest producer of oil palm is lagging behind in this regard.

This call for urgent step in this direction to help safe guard the area before it becomes too late. This can only be possible if there is increasing funding for research for all taxa in the area. The outcome will guide policy makers on more informed decisions that will help safe guide Oban hills region from this emerging threat of oil palm plantation

\section{CONCLUSION}

It is very obvious that poverty is a major obstacle to human development that every meaningful government will want to eradicate. However, the use of oil palm plantation expansion as a strategy for poverty reduction has very serious ecological, economical and social impacts. Scholars believe that, with continuing expansion meaning that there is a limited timeframe in which to act if we are to stand a chance of mitigating these impacts. Survival of Oban hills region depends on how fast we can act collectively 
Oil Palm Plantation Development: An Emerging Threat to Biodiversity Conservation in Oban Division of Cross River National Park, Nigeria

\section{REFERENCE}

[1] Akangbe JA, Adesiji G B, Fakayode S B and Aderibigbe YO 2011. Towards Palm Oil Self-sufficiency in Nigeria: Constraints and Training needs Nexus of Palm Oil Extractors. J Hum Ecol, 33.2: 139-145

[2] Anderson J, Benjamin C, Campbell B and Tiveau D 2006. Forests, poverty and equity in Africa: new perspectives on policy and practice. International Forestry Review.8.1: 44-52

[3] Aratrakorn S, Thunhikorn S, et al. (2006). "Changes in bird communities following conversion of lowland forest to oil palm and rubber plantations in southern Thailand." Bird Conservation International 16.1: 71-82.

[4] Ayodele T 2010. African Case Study: Palm Oil and Economic Development in Nigeria and Ghana; Recommendations for the World Bank's 2010 Palm Oil Strategy. Retrieved from www.ippanigeria.org/worldbankreportpal moil[1].pd on 26-08-2014

[5] Bergl R A, Oates JF and Fotso R 2006. Distribution and protected area coverage of endemic taxa in West Africa's Biafran forests and highlands Bio. Cons.1 3 4:1 95 $-208$

[6] Bernard H, Fjeldså J, et al. 2009. "A case study on the effects of disturbance and conversion of tropical lowland rain forest on the non-volant small mammals in north Borneo: Management implications." Mammal Study 34: 85-96

[7] Brühl CA and Eltz T 2010. "Fuelling the crisis: Species loss of ground-dwelling forest ants in oil palm plantations in Sabah, Malaysia (Borneo)." Biodiversity \&Conservation 19.2: 519-529

[8] Butchart SHM, Stattersfield AJ, Bennun LA, Shutes SM, Akçakaya HR, Baillie JEM, Stuart SN, Hilton-Taylor C and Mace GM 2004. Measuring Global Trends in the Status of Biodiversity: Red List Indices for Birds. PLoS Biol 2.12: e383. doi:10.1371/journal.pbio.0020383

[9] Butler RA and Laurance WF 2009. Is oil palm the next emerging threat to the Amazon? Trop Conserv Sci 2:1-10

[10] Chey V 2006. "Impacts of Forest Conversion on Biodiversity as Indicated by
Moths."Malayan Nature Journal 57.4: 383418.

[11] CIFOR, 2005. Contributing to Africa's Development Through Forests Strategy for Engagement in sub-Saharan Africa, Center for International Forestry Research, Bogor, Indonesia $35 \mathrm{pp}$.

[12] Danielsen F, Beukema H, Burgess ND, Parish F, Bruhl CA, Donald PF, Murdiyarso D,

[13] Phalan B, Reijnders L, Struebig $M$ and Fitzherbert EB 2009. Biofuel plantations on forested lands: double jeopardy for biodiversity and climate. Conserv Biol 23:348-358

[14] Daramola AM, Igbokwe EM, Mosuro GA and Abdullahi JA 2002. Examination Focus, Agricultural Science. Ibadan: Ibadan University Press Plc

[15] Edwards DP, Hodgson JA, Hamer KC, Mitchell SL, Ahmad AH, Cornell SJ and Wilcove DS 2010. Wildlife-friendly oil palm plantations fail to protect biodiversity effectively. Conservation Letters 3: 236242

[16] Davis A and Philips K 2005. "Effect of Deforestation on a Southwest Ghana Dung Beetle Assemblage (Coleoptera: Scarabaeidae) at the Periphery of Ankasa Conservation Area." Environmental Entomology 34.5: 1081-1088.

[17] Fayle TM, Turnera EC, Snaddona JL, Chey VK, Chung AYC, Eggleton P and Fostera WA 2010. "Oil palm expansion into rain forest greatly reduces ant biodiversity in canopy, epiphytes and leaflitter." Basic and Applied Ecology. 337345

[18] Fitzherbert EB, Struebig MJ, Morel A, Danielson F, Bruhl CA, Donald PF and Phalan B 2008. How will oil palm expansion affect biodiversity? Trends Ecol Evol 23:538-545

[19] Ingwe R, Ikeji, CCC and Mboto W 2010. Forestry, Poverty Alleviation and Human Livelihoods Support in Cross River State, Nigeria: An Analysis of Sub-National Agro-Forestry Development Policy in a Poverty-Stricken Bioregion. Journal of Sustainable Development in Africa 2.2:414442

[20] Ite UE and Adams WM 1998. Forest conversion, conservation and forestry in 
Oil Palm Plantation Development: An Emerging Threat to Biodiversity Conservation in Oban Division of Cross River National Park, Nigeria

Cross River State, Nigeria. App. Geo. 18.4: 301-314.

[21] Jimoh SO, Ikyaagba ET, Aralape AA, Adeyemi AA and Waltert M 2012b. Local depletion of two larger Duikers in the Oban Hills Region, Nigeria Afr. J. Ecol. 51: 228234

[22] Khalil M 1995. Biodiversity the conservation of medicinal plants: Issues from the perspective of the developing world. Intellectual property Rights and biodiversity conservation: T Swanson (ed). $232-253 \mathrm{Pp}$.

[23] Koh LP 2008. Can oil palm plantations be made more hospitable for forest butterflies and birds? J Appl Ecol 45:1002-1009

[24] Liow LH, Sodhi N S and Elmqvist T 2001. "Bee diversity along a disturbance gradient in tropical lowland forests of south-east Asia." Journal of Applied Ecology 38.1: 180-192.

[25] Myers N, Mittermeier RA, Mittermeier CG, Da Fonseca GAB and Kent J 2000. Biodiversity hotspots for conservation priorities. Nature 403: 853-858.

[26] Nkwatoh AF, Popool L, Mosua IS Nkwatoh FW, Ndumbe NL. and Ewane M E. Harvesting and marketing of Gnetum species (Engl) in Cameroon and Nigeria. Journal of Ecology and the Natural Environment 2.9:187-193

[27] Oates JF, Berg RA, Linder JM 2004. Africa's Gulf of Guinea Forests: Biodiversity Patterns

[28] and Conservation Priorities: Advances in Applied Biodiversity Science, number 6.Conservation International, Washington D.C. retrieved from s3.amazonaws.com/.../file_20110823_0345 57_Oates+Africa+Gulf+Guin. On 22-122011

[29] Obong LB, Aniah EJ, Okaba LA, Effiom VA 2013. Sustainable Livelihood in the Cross River National Park (CRNP), Oban Division, Nigeria International Journal of Business and Social Science . 4.16: 219231

[30] Offiong, E. E and Ita , P. B. 2013. NonTimber Forest Products for Food Security and Development in Nigeria. AJSIH 3.4: 159-168

[31] Ogar D, Agbor C, Eyamba F and Adeleke W 2005 The Significance of Bush-meat and Timber trade in Local and State Economies of Cross River State. SPACE Study Report - 3rd Draft.

[32] Oksanen T, Pajari B and Tuomasjukka T 2003. Executive summary. In: Oksanen, T., Pajari, B. and Tuomasjukka, T. (eds.) Forests in poverty reduction strategies: capturing the potential, pp. 7-15. EFI Proceedings No 47. European Forest Institute: Joensuu, Finland.

[33] Olagunju FI 2008. Economics of Palm Oil Processing in Southwestern Nigeria. International Journal of Agricultural Economics \& Rural Development 1.2: 6977

[34] Osagies C 2013. PZ Wilmar: Reshaping Oil Palm Industry with Massive Plantation Development Retrieved from http://www.thisdaylive.com/articles/pzwilmar-reshaping-oil-palm-industry-withmassive-plantation-devt/146938/ on 26-082014

[35] Persey S and Anhar S 2010. Biodiversity Information for Oil Palm. International Conference on Oil Palm and Environment 2010, Bali, INDONESIA. retrieved from www.ibrarian.net/.../Biodiversity_Informati on_for_Oil_Palm_Sophie_Pe. on 10-52013.

[36] Reid JC 1989. Flora and Fauna Richness of the Oban Division of the CRNP. Appendix 7 CRNP (Oban Division) Plan for Developing the Park and its Support Zone, WWF, Gland Switzerland

[37] Richards PW 1996. The Tropical Rain Forest. Cambridge: Cambridge University

[38] Rist L, Feintrenie L, Levang P 2010. “I want to change my fate now!" The livelihood impacts of oil palmin Indonesia. Biodivers Conserv

[39]

Schmit K 1996.

Botanical survey in the Oban Division of CRNP - Technical Report on Oban Hill progamm Calabar 1-55pp

[40] Turner EC, Snaddon JL, Fayle TM and Foster WA 2008. Oil Palm Research in Context: Identifying the Need for Biodiversity Assessment. PLoS ONE 3.2: 1-4. e1572. doi:10.1371/journal.pone. 0001572.

[41] Ugwu DS 2009. Problems and Prospects of Commercial Small and Medium Scale Cocoa and Oil Palm Production in Cross 
Oil Palm Plantation Development: An Emerging Threat to Biodiversity Conservation in Oban Division of Cross River National Park, Nigeria

River State, Nigeria Journal of Applied Sciences Research, 5.7: 827-832,

[42] Waltert M, Bobo K., Ngalim OY, Gorschluter L and Kiffener C 2011. Is it Really 'All for Africa?'- The Fraudulent Social and Ecological Argumentation of oil palm developing Institutions. Development on the Margin. Book of abstracts. International Research on Food Security,
Natural Resources Management and Rural Development. (TROPENTAG 2011). University of Bonn, Bonn 5-7 October, 2011, p35.

[43] Wilcove DS and Koh LP 2010. Addressing the threats to biodiversity from oil-palm agriculture. Biodivers Conserv 19: 9991007

Citation: Ikyaagba, E .T et al. "Oil Palm Plantation Development: An Emerging Threat To Biodiversity Conservation In Oban Division Of Cross River National Park, Nigeria". International Journal of Research in Agriculture and Forestry 4.4 (2017): 5-11.

Copyright: () 2017 Ikyaagba, E .T et al. This is an open-access article distributed under the terms of the Creative Commons Attribution License, which permits unrestricted use, distribution, and reproduction in any medium, provided the original author and source are credited. 